\title{
(5)

\section{Forstørrede lymfeknuter og utslett hos en mann fra et middelhavsland}

NOE Å LAERE AV

\section{MARJUT SARJOMAA}

E-post: sarm@sthf.no

Medisinsk klinikk

Sykehuset Telemark

Marjut Sarjomaa er spesialist i infeksjonssykdommer og overlege.

Forfatteren har fylt ut ICMJE-skjemaet og oppgir ingen interessekonflikter.

\section{BERNARD MAJAK}

Seksjon for patologi

Sykehuset Telemark

Bernard Majak er ph.d., spesialist i patologi og Fellow of the International Academy of Cytology.

Forfatteren har fylt ut ICMJE-skjemaet og oppgir ingen interessekonflikter.

\section{THOMAS LUDOLPH}

Klinik für Innere Medizin, Schwerpunkt Gastroenterologie

Kreiskrankenhaus Frankenberg

Tyskland

Thomas Ludolph er spesialist i gastroenterologi og klinikksjef.

Forfatteren har fylt ut ICMJE-skjemaet og oppgir ingen interessekonflikter.

\section{MAGNUS LØBERG}

Institutt for helse og samfunn

Universitetet i Oslo

og

Avdeling for transplantasjonsmedisin

Oslo universitetssykehus

Magnus Løberg er førsteamanuensis og forsker. Han jobbet tidligere som lege i spesialisering på medisinsk avdeling ved Sykehuset Telemark.

Forfatteren har fylt ut ICMJE-skjemaet og oppgir ingen interessekonflikter.

En mann fra et middelhavsland hadde tilbakevendende forstørrede lymfeknuter, feber og utslett. Kasuistikken illustrerer en uvanlig sykdom i Norge og utfordringer ved utredning og behandling.

En mann med opprinnelse fra et middelhavsland hadde vært bosatt i Norge i mange år da han ble henvist fra fastlege til kirurgisk poliklinikk grunnet forstørrede lymfeknuter i høyre armhule. Disse hadde pasienten oppdaget omtrent to uker tidligere. Han hadde ingen feber eller allmennsymptomer. Ved undersøkelse var det multiple lymfeknuter, og den største lymfeknuten var $3 \mathrm{~cm}$ i diameter. I armhulen og på ryggen hadde han pustler som ga mistanke om en hudinfeksjon med stafylokokker. Blodprøver var normale bortsett fra CRP 
som var $15 \mathrm{mg} / \mathrm{l}$ (referanseområde $<5 \mathrm{mg} / \mathrm{l})$. SR var $11 \mathrm{~mm} /$ time $(<13 \mathrm{~mm} /$ time). Ultralyd av armhulen viste patologisk forstørrede lymfeknuter. CT av thorax og abdomen to uker senere viste flere forstørrede lymfeknuter lokalt i høyre armhule og flere grensestore lymfeknuter retroperitonealt, for øvrig normal lever og milt. Cytologisk undersøkelse av finnålsaspirasjon fra den største lymfeknuten tre uker etter første konsultasjon viste lymfoplasmacytoide celler og epiteloide celler. Det var ingen syrefaste staver i ZiehlNeelsen-farget cytologivæske av lymfeknuten, og mykobakteriedyrkning var negativ. Det ble ikke påvist antistoffer mot hiv. Pasienten ble behandlet med dikloksacillintabletter for hudabscessene, som deretter forsvant. Før planlagt lymfeknutebiopsi hadde lymfeknutene avtatt betydelig i størrelse, og man valgte derfor å avlyse inngrepet.

Hudforandringer med små pustler kan gi mistanke om hudabscesser med gule stafylokokker. En bakteriologisk dyrkningsprøve kan avklare det. Lymfeknuter vil være forstørrede ved en slik bakteriell infeksjon. Der infeksjon ikke kan forklare forstørrede lymfeknuter, er cytologi og histologi av lymfeknuten viktig for å utelukke lymfom eller metastaser fra kreftsykdom. Hos personer fra land med høy forekomst av tuberkulose må lymfeknutetuberkulose utelukkes med Ziehl-Neelsen-farging og mykobakteriedyrkning.

To og et halvt år senere ble pasienten innlagt akutt med feber, frostrier, nattesvette, kvalme og oppkast, som han hadde vært plaget av i to uker. Han hadde hatt et ufrivillig vekttap på $10 \mathrm{~kg}$ det siste halve året. Ved innkomst fant man igjen lymfeknutesvulst i høyre armhule. Temperaturen var $38,1{ }^{\circ} \mathrm{C}$ målt rektalt, men for $\emptyset$ vrig var intet unormalt ved klinisk undersøkelse. Laboratorieprøver viste SR $33 \mathrm{~mm} / \mathrm{t}(<13 \mathrm{~mm} / \mathrm{t}), \mathrm{Hb} 11,2 \mathrm{~g} / \mathrm{dl}(13,4-17 \mathrm{~g} / \mathrm{dl})$, leukocytter $5,7 \cdot 10^{9} / \mathrm{l}\left(3,5-11 \cdot 10^{9} / \mathrm{l}\right)$, trombocytter $219 \cdot 10^{9} / \mathrm{l}\left(145-348 \cdot 10^{9} / \mathrm{l}\right)$, kreatinin 54 $\mu \mathrm{mol} / \mathrm{l}(6 \mathrm{o}-105 \mu \mathrm{mol} / \mathrm{l}), \mathrm{s}-\mathrm{kalsium} 2,11 \mathrm{mmol} / \mathrm{l}\left(2,15^{-2,51} \mathrm{mmol} / \mathrm{l}\right)$, alkalisk fosfatase $357 \mathrm{U} / \mathrm{l}$ (35-105 U/l), ALAT $114 \mathrm{U} / \mathrm{l}(10-70 \mathrm{U} / \mathrm{l})$, LD $191 \mathrm{U} / \mathrm{l}(105-205 \mathrm{U} / \mathrm{l})$, glukose $4,9 \mathrm{mmol} / \mathrm{l}$ (4-6 mmol/l), albumin $33 \mathrm{~g} / \mathrm{l}(36-45 \mathrm{~g} / \mathrm{l})$ og CRP $121 \mathrm{mg} / \mathrm{l}(<5 \mathrm{mg} / \mathrm{l})$. CT tatt under innleggelsen viste lymfeknutesvulst i høyre armhule, forstørret milt $(13 \times 15 \mathrm{~cm}), \varnothing \mathrm{kt}$ antall og størrelse av lymfeknuter ved leverhilus, retroperitonealt, langs bekkenkar og i begge lysker. Mantoux' prøve var normal, og s-ACE 101 U/1 (20-110 U/I). Det var derfor ikke sterk mistanke om tuberkulose eller sarkoidose. Beinmargsbiopsi fra hoftekam tatt under oppholdet viste ingen tegn til lymfom eller sarkoidose, men enkelte dysplastiske trekk som ut fra kliniske undersøkelser ble oppfattet som reaktive forandringer. Det ble fjernet en lymfeknute fra høyre armhule, og histologisk undersøkelse beskrives slik: «Lymfeknute fra høyre aksille med eiendommelig karproliferasjon i sinus og perilymfatisk vev.» Etter ti dager hadde man ikke kommet frem til endelig diagnose, og pasienten ble skrevet ut uten behandling. Sarkoidose ble regnet som mest sannsynlig selv om nivået av angiotensinkonverterende enzym (ACE) var normalt.

Sarkoidose blir ofte oppdaget som et tilfeldig funn på røntgen thorax. Symptomene er uspesifikke og inkluderer tretthet, irritasjonshoste, nattesvette, feber og vektnedgang. Hyppigste funn på røntgen thorax er bilateral hilusadenopati og både diffuse og fokale lungeparenkymforandringer. ACE er den viktigste biokjemiske testen. Ved Löfgrens syndrom, som er en akutt form, forekommer bilateral hilusadenopati, erythema nodosum og leddsmerter. Det finnes ingen definitive diagnostiske tester for sarkoidose (1). Hos denne pasienten var den tentative diagnosen basert på det kliniske bildet og eksklusjon av sentrale differensialdiagnoser. Biopsi fra lymfeknuten og beinmargsbiopsi ga ikke holdepunkter for lymfom. Det var vanskelig å tolke funnet i lymfeknutebiopsien, men den ble ikke sendt videre til fornyet vurdering.

Videre poliklinisk utredning med serumelektroforese viste ingen monoklonal komponent, hvilket utelukket myelomatose, mens immunglobuliner var innenfor normalområdet. CT av thorax og abdomen et halvt år etter første innleggelse viste progresjon av lymfeknutesvulst i begge armhuler og abdominalt. Pasienten motsatte seg ny beinmargsbiopsi, og det ble derfor bare tatt sternalmargsaspirasjon, som viste normale funn. Serologisk fant man at pasienten hadde gjennomgått infeksjon med Epstein-Barrvirus, cytomegalovirus og hepatitt B. For øvrig var det ved serologisk undersøkelse ingen 
tegn til syfilis, hepatitt A eller C, toksoplasmose eller borreliose. Mycoplasma pneumoniaePCR og gjentatt hiv-test var negativ, og det samme var revmatoid faktor (RF), antinukleære antistoffer (ANA) og antistoffer mot sykliske citrullinerte peptider (anti-CCP). En revmatologisk sykdom som leddgikt var derfor lite sannsynlig.

Tre år etter første konsultasjon ble pasienten innlagt akutt med hoste. Røntgen ga mistanke om pneumoni. Behandling med G-penicillin $(5$ mill. IE $\times 4$ intravenøst) var vellykket. Under innleggelse utviklet han nyresvikt med kreatinin $471 \mu \mathrm{mol} / \mathrm{l}(6 \mathrm{o}-105 \mu \mathrm{mol} / \mathrm{l})$ og urea $38,2 \mathrm{mmol} / \mathrm{l}(3,5-8,1 \mathrm{mmol} / \mathrm{l})$. Man fant ingen pre- eller postrenal årsak til nyresvikten, og det var ikke behov for dialyse. Det ble tatt nyrebiopsi, som viste nyrevev med granulomatøs, interstitiell nefritt, og det ble startet behandling med kortikosteroider, først metylprednisolon intravenøst (1 $\mathrm{g}$ daglig $\mathrm{i}$ tre dager) og deretter prednisolon peroralt (6o mg daglig med nedtrapping). På steroidbehandling gikk nyresvikten tilbake. Gastroskopi, som ble utført på grunn av fall i $\mathrm{Hb}$ fra 12,8 g/dl til 9,5 g/dl, var helt normal. Pasienten ble skrevet ut med prednisolonkur i nedtrappende doser.

Sarkoidose var en av differensialdiagnosene sammen med mulig medikamentell eller infeksiøs årsak for lungeaffeksjon og nefritt med nyresvikt. I anamnesen var det ingen holdepunkter for nye medikamenter, og infeksiøs årsak ble ikke bekreftet i nyrebiopsien. Man konkluderte med at pasienten mest sannsynlig hadde sarkoidoserelatert nefritt.

Det følgende året ble pasienten fulgt opp regelmessig på kreftpoliklinikken. Prednisolondosen ble trappet ned, men han var avhengig av en vedlikeholdsdose på $10 \mathrm{mg}$ daglig for å unngå symptomer med feber og slapphet. Han gikk 1o kg opp i vekt som bivirkning av kortison og utviklet hypertensjon som krevde medikamentell behandling. Ett år etter oppstart av høydosebehandling med kortison ble mannen igjen akutt innlagt på sykehuset. Denne gangen hadde han temperatur på $40,2{ }^{\circ} \mathrm{C}$, kvalme og oppkast, og smerter i begge flanker. Han hadde helt nylig kommet hjem fra ferie i hjemlandet. Det ble startet antibiotikabehandling med G-penicillin og tobramycin intravenøst. CRP steg til $260 \mathrm{mg} / \mathrm{l}$, og blodkulturer viste oppvekst av Salmonella enteritidis. Behandlingen ble etter resistensbestemmelse skiftet til ciprofloksacin (400 mg intravenøst tre ganger daglig), og pasienten ble raskt symptomfri. En måned senere hadde han tilbakefall av symptomer og ble igjen innlagt med salmonellasepsis, som responderte godt på ciprofloksacin. Ytterligere en måned etter ble han akutt innlagt med leddsmerter, som ble tolket som reaktiv artritt etter salmonellainfeksjon. Han viste i tillegg frem noen uvanlige utslett på underarmen, som ble tolket som mulig prednisolonbivirkning.

To måneder etter siste innleggelse ble pasienten innlagt med symptomer på luftveisinfeksjon uten respirasjonssvikt, og man startet med både sepsisbehandling og behandling med oseltamivir. Fem dager tidligere var han vaksinert for ny influensa ( $\left.\mathrm{H}_{1} \mathrm{~N}_{1}\right)$. Virusprøve fra nese og svelg var positiv for $\mathrm{H}_{1} \mathrm{~N}_{1}$, noe som betydde at han ikke hadde fått effekt av vaksinen etter så kort tid. Han ble etter et kort opphold utskrevet med beskjed om å fortsette oseltamivirbehandlingen hjemme.

Etter denne episoden ble han ikke ordentlig bra. Han ble nok en gang innlagt og gastroskopert, og i ventrikkelen så man tre rødlige, puteformede forandringer med hemangiomaktig utseende. Forandringene ble biopsert. Ved sammenligning av makroskopisk gastroskopifunn med endoskopiatlas så man at funnet var patognomisk for gastrointestinalmanifestasjon av Kaposis sarkom (2). Patologen ble bedt om å undersøke ventrikkelbiopsier med tanke på dette. Pasienten viste også frem blålilla hudforandringer både på høyre underarm og venstre vrist som hadde $ø \mathrm{kt}$ i størrelse de siste fem månedene (figur 1). Hudforandringer på armen ble biopsert, og histologisk undersøkelse bekreftet Kaposis sarkom både i ventrikkel-(figur 2) og hudbiopsi. Begge biopsiene viste HHV-8positivitet (humant herpesvirus 8). Lymfeknutebiopsien fra fem år tidligere ble revurdert til også å være forenelig med Kaposis sarkom (figur 3). Etter at diagnosen var stilt, ble det startet behandling med liposomalt doksorubicin intravenøst. På tross av behandlingen utviklet sykdommen seg videre med spredning til leveren, og pasienten døde litt over to år etter at diagnosen var stilt. 


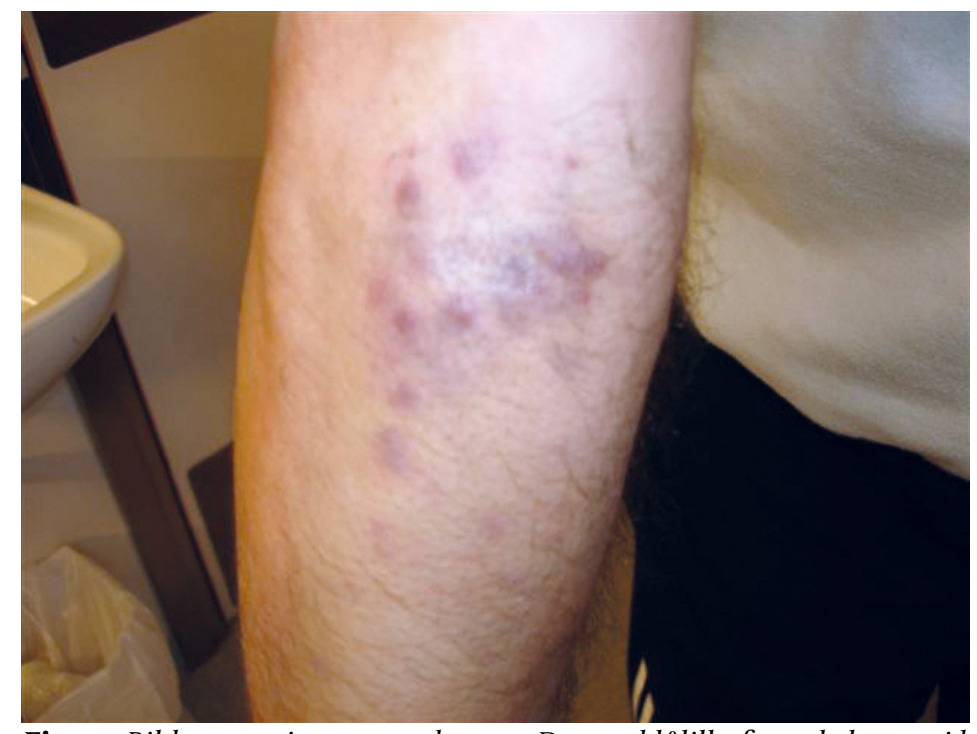

Figur 1 Bilde av pasientens underarm. Det ses blålilla-fargede knuter i huden.

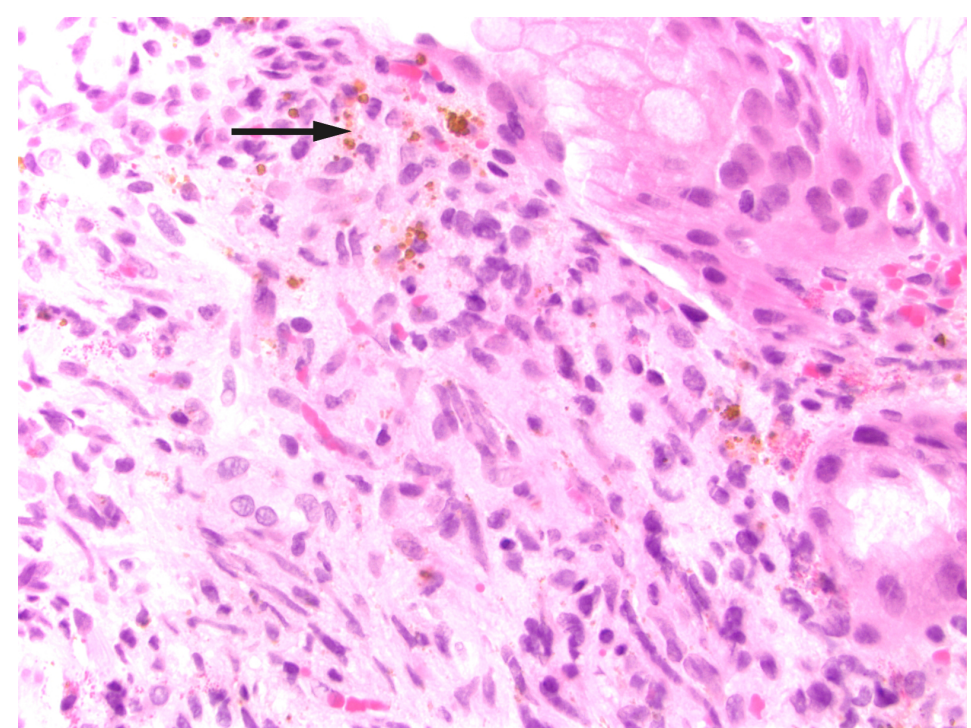

Figur 2 Biopsi fra ventrikkelslimhinnen med kapillcer proliferasjon, ekstravaserte erytrocytter og hemosiderin (pil). En mitose i spoleformet, stromal celle. HE-farget (hematoksylin-eosin).

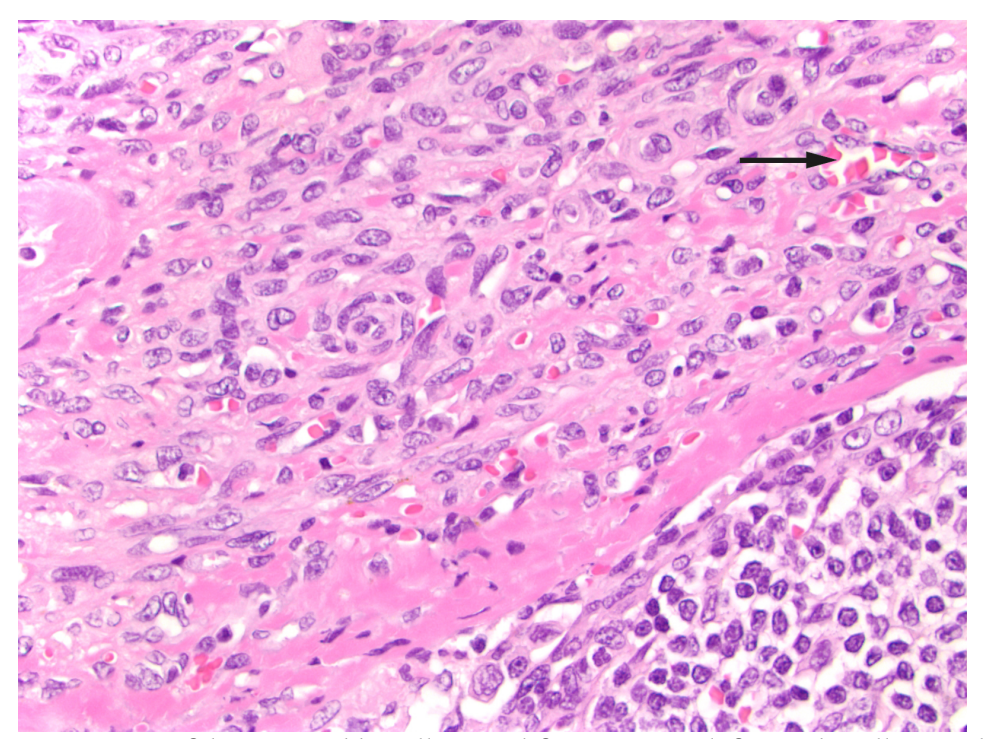

Figur 3 Lymfeknute med kapillcer proliferasjon. Spoleformede celler og ekstravaserte erytrocytter $i$ kapselen (pil). Normal lymfoid follikkel nederst til høyre. HE-farget (hematoksylin-eosin).

\section{Diskusjon}

Hos vår pasient var tilbakevendende feber og forstørrede lymfeknuter de dominerende symptomer og funn over lang tid. Underveis mistenkte man sarkoidose med nyreaffeksjon, 
da det passet godt med sykehistorien, og man ikke fant annen sannsynlig diagnose. Etter langvarig utredning fikk pasienten påvist klassisk Kaposis sarkom med affeksjon av hud og viscera (ventrikkelen). Immunsuppressiv behandling er en medvirkende faktor for klinisk sykdomsutvikling av Kaposis sarkom, men vår pasient ble først behandlet med kortison når sykdomsbildet allerede var fullt utviklet. Kortison kan likevel ha hatt betydning for utvikling av lesjoner på huden og viscera (3). Over flere år hadde pasienten mange innleggelser med infeksjoner, men vi fant aldri tegn til immunsvikt. Nyrebiopsien ble revurdert av en patolog etter at diagnosen Kaposis sarkom var stilt, men patologen kunne ikke finne typiske histopatologiske tegn passende til denne sykdommen. Det er usikkert om Kaposis sarkom kan forklare hele sykdomsforløpet hos denne pasienten. Underveis hadde han flere alvorlige infeksjonssykdommer og fikk påvist interstitiell nefritt av usikker årsak. Noen av disse samtidige tilstandene kan neppe forklares med Kaposis sarkom, og de kan dermed forvirre klinikeren i det diagnostiske arbeidet. Fem år før diagnosetidspunktet ble det tatt en lymfeknutebiopsi fra armhulen som ble beskrevet som eiendommelig, men hvor man ikke kom til noen klar konklusjon. Ved regransking viste den seg å være forenelig med Kaposis sarkom. Kanskje kunne diagnosen vært stilt tidligere om denne biopsien hadde blitt sendt til second opinion.

Kaposis sarkom er en multifokal, lavgradig, vaskulær tumor som involverer hud, mukosa og viscera (3). Sykdommen ble først beskrevet i fem kasuistikker av den østerrikske legen Moritz Kaposi i 1872, og han kalte tilstanden «idiopathic multiple pigmented sarcoma» (4, 5). I kasuistikkene beskrev han ødem og blålilla noduler på huden, mest på hendene og føttene. Ved mikroskopisk undersøkelse av hudbiopsier beskrev han små runde celler (spolceller), små hemorragiske områder med noduler og pigment (hemosiderin). Alle pasientene døde i løpet av to-tre år.

I 1994 identifiserte man herpesviruslignende DNA-sekvenser hos aidspasienter som var assosiert med Kaposis sarkom (6), og disse ble kalt humant herpesvirus 8 (HHV-8). HHV-8 er medlem av gammaherpesvirusfamilien. Gammaherpesvirus forårsaker svulster, lymfoproliferative sykdommer og lymfomer hos mennesker og dyr. Man mistenker at HHV-8 ble spredt fra dyr i Afrika til mennesker i middelhavslandene. De fleste primære HHV-8-infeksjoner er asymptomatiske (3). Eksakt virustransmisjon er ikke kjent, men virus spres ved seksuell omgang, og man finner virus også i spytt. Mor-barn-transmisjon av virus er påvist i Afrika (7). HHV-8 er nødvendig, men ikke tilstrekkelig, for utvikling av Kaposis sarkom (3).

Sykdomsutvikling er avhengig av medvirkende faktorer som kronisk inflammasjon og immunsuppresjon (8). Hiv fremmer HHV-8-virusreplikasjonen indirekte ved å nedregulere immunsystemet og med produksjon av cytokiner. Kaposis sarkom er den vanligste svulsten hos pasienter med aids, men hiv kan ikke alene forårsake Kaposis sarkom (6).

Det er stor variasjon i prevalens av HHV-8, fra høyendemiske områder i Afrika sør for Sahara (30-70 \%) via intermediær høy prevalens i middelhavslandene (5-20\%) til lav prevalens i Nord-Europa og Japan $(<5 \%)(3,9)$. HHV-8-prevalens gjenspeiler forekomsten av Kaposis sarkom i disse landene. Det rapporteres årlig bare tre-ni tilfeller av Kaposis sarkom til Kreftregisteret i Norge (2003-2012) (10).

Man deler sykdommen inn i fire former basert på epidemiologi, tilgrunnliggende årsak og klinisk utbredelse. Det er stort overlapp mellom formene både når det gjelder klinikk og prognose, men de mer indolent forløpende tilfellene har mest hudforandringer, mens de mer aggressivt forløpende i større grad involverer mucosa og viscera. Klassisk Kaposis sarkom forekommer oftest hos eldre menn fra Øst-Europa og middelhavslandene. Endemisk Kaposis sarkom var den vanligste formen i Afrika før aids-epidemien. I Uganda utgjorde Kaposis sarkom 3-9\% av alle krefttilfeller i 1971. Aidsassosiert Kaposis sarkom har blitt den dominerende formen i Afrika fra 1980-årene. Aidsassosiert Kaposis sarkom har et mer aggressivt forløp enn endemisk Kaposis sarkom, men kan bremses eller gå i regress ved god hiv-behandling. Iatrogen Kaposis sarkom sees hos immunsupprimerte organtransplanterte pasienter, spesielt hos etniske grupper som er utsatt for klassisk Kaposis sarkom i 
middelhavslandene (3). Den aktuelle pasienten passer best inn i kategorien klassisk Kaposis sarkom, hovedsakelig på bakgrunn av herkomst og fravær av hiv-infeksjon og iatrogen immunsuppresjon.

Histopatologiske funn er identiske ved de fire formene, og det typiske histologiske funnet er spolceller. Sykdommen progredierer i tre histologiske stadier: Det første kalles "patch stage» og er preget av flate, makuløse forandringer. Neste stadium kjennetegnes av plakk, mens det siste, tumorstadiet, preges av nodulære lesjoner. De histologiske forandringene kan lett oversees (5).

Behandling av Kaposis sarkom varierer avhengig av den kliniske formen og symptomer. Ved fravær av symptomer kan behandling avventes. Aktuelle behandlingsformer er kirurgisk eksisjon, lokalbehandling med interferon alfa-2b, strålebehandling og systemisk kjemoterapi (5). Siden det ikke finnes behandling for å eradikere HHV-8, er det omdiskutert om Kaposis sarkom kan kureres (11). Kaposis sarkom som er begrenset til huden, responderer normalt godt på kjemoterapi, mens nodulære lesjoner er assosiert med kortere progresjonsfri overlevelse (12). Det finnes få retningslinjer for behandling, og forløpet av sykdommen ved ulike former for behandling er hovedsakelig beskrevet i retrospektive observasjonelle studier med sprikende funn. I en studie hadde $55,5 \%$ av pasientene progresjon av sykdommen, og 2,3\% var døde av Kaposis sarkom etter median oppfølging på 28 måneder (12). I en annen studie var median progresjonsfri overlevelse 11,7 måneder etter systemisk kjemoterapi, mens halvparten var døde innen 28,5 måneder (13). I en studie fra Italia fant man at bare $\mathbf{1 2 , 2} \%$ av pasienter med Kaposis sarkom døde av tilstanden. Imidlertid var dette en kohort av eldre pasienter (median alder ved tidspunkt for død var 82 år for kvinner og 85 år for menn), og de fleste døde av hjerte- og karsykdommer (14).

\section{Konklusjon}

Kasuistikken beskriver et langtrukkent og utfordrende diagnostisk arbeid som til slutt endte med at pasienten ble diagnostisert med Kaposis sarkom. Kaposis sarkom er en sjelden forekommende kreftform i Norge. De fleste tilfeller forekommer hos middelaldrende menn fra middelhavslandene og hos pasienter med aids (10). Siden tilstanden er sjelden, og fordi både klinikk og histopatologiske funn er uspesifikke, kan diagnostikken være krevende.

\footnotetext{
LITTERATUR:

1. Talmadge E. King, Jr. Clinical manifestations and diagnosis of pulmonary sarcoidosis. UpToDate. https://www.uptodate.com/contents/clinical-manifestations-and-diagnosis-of-pulmonary-sarcoidosis (7.11.2018).

2. Silversten FE, Tytgat GNJ. Atlas of gastrointestinal endoscopy. Philadelphia: Lippincott Williams and Wilkins, 1991: 170 .

3. Antman K, Chang Y. Kaposi's sarcoma. N Engl J Med 2000; 342: 1027-38. [PubMed][CrossRef]

4. Braun M. Classics in Oncology. Idiopathic multiple pigmented sarcoma of the skin by Kaposi. CA Cancer J Clin 1982; 32:340-7. [PubMed][CrossRef]

5. Pantanowitz L, Grayson W, Simonart T et al. Pathology of Kaposi's sarcoma. J HIV Ther 2009; 14: 41-7. [PubMed]

6. Chang Y, Cesarman E, Pessin MS et al. Identification of herpesvirus-like DNA sequences in AIDSassociated Kaposi's sarcoma. Science 1994; 266:1865-9. [PubMed][CrossRef]

7. Bagni R, Whitby D. Kaposi's sarcoma-associated herpesvirus transmission and primary infection. Curr Opin HIV AIDS 2009; 4: 22-6. [PubMed][CrossRef]
}

8. Pantanowitz L, Moses AV, Dezube BJ. The inflammatory component of Kaposi sarcoma. Exp Mol Pathol 2009; 87: 163-5. [PubMed][CrossRef]

9. Mwakigonja AR, Pyakurel P, Kokhaei P et al. Human herpesvirus-8 (HHV-8) sero-detection and HIV 
association in Kaposi's sarcoma (KS), non-KS tumors and non-neoplastic conditions. Infect Agent Cancer 2008; 3: 10. [PubMed][CrossRef]

10. Cancer Registry of Norway. Cancer in Norway 2012 - Cancer incidence, mortality, survival and prevalence in Norway. Oslo: Kreftregisteret, 2014.

https://www.kreftregisteret.no/globalassets/cancer-in-norway/2012/cin_2012-web.pdf(29.11.2018).

11. Jakob L, Metzler G, Chen KM et al. Non-AIDS associated Kaposi's sarcoma: clinical features and treatment outcome. PLoS One 2011; 6: e18397. [PubMed][CrossRef]

12. Sen F, Tambas M, Ciftci R et al. Factors affecting progression-free survival in non-HIV-related Kaposi sarcoma. J Dermatolog Treat 2016; 27: 275-7. [PubMed][CrossRef]

13. Rescigno P, Di Trolio R, Buonerba C et al. Non-AIDS-related Kaposi's sarcoma: A single-institution experience. World J Clin Oncol 2013; 4: 52-7. [PubMed][CrossRef]

14. Ascoli V, Minelli G, Kanieff M et al. Cause-specific mortality in classic Kaposi's sarcoma: a population-based study in Italy (1995-2002). Br J Cancer 2009; 101:1085-9o. [PubMed][CrossRef]

Publisert: 22. mars 2019. Tidsskr Nor Legeforen. DOI: 10.4045/tidsskr.18.0514

Mottatt 13.6.2018, første revisjon innsendt 8.11.2018, godkjent 29.11.2018.

(C) Tidsskrift for Den norske legeforening 2020. Lastet ned fra tidsskriftet.no 